\title{
THE ACTIONS CARRIED OUT BY THE CYBERPARC INCUBATOR OF SIDI ABDELLAH DURING THE PERIOD OF 2010-2020: STATE OF PLAY AND PERSPECTIVES
}

\author{
Zina ARABECHE* \\ University Ahmed Zabana of Relizane, Lapdec Laboratory (University of Mascara), \\ Algeria \\ *Corresponding author's e-mail: Zina.arabeche@univ-relizane.dz
}

\begin{abstract}
This paper aims to describe the actions carried out by the Cyber-park incubator of Sidi Abdellah during the period of 2010-2020 in order to support young project holders. The Cyber-park of Sidi Abdellah is the first Algerian experience of creating a technology park. The project is very ambitious; it reflects the Algerian political will to build an information society and accelerate the transition of Algeria to a knowledge economy. However, through our reading of the statistics provided, we can say that the number of project holders affiliated to the incubator of Sidi Abdullah, especially the number of projects accepted, is still far from the objectives presented by the incubator. On the other hand, we have found that the Cyber-park incubator focuses much more on the training of entrepreneurs, while the financial side is totally absent.
\end{abstract}

Keywords: Algeria, business incubator, cyber-park incubator of Sidi Abdellah, entrepreneurs, support

JEL Classification: L25, L26, L53

\section{INTRODUCTION}

The incubation programme is widely regarded as a critical policy tool for boosting local innovation and economic growth (Wonglimpiyarat, 2016; Lukes, Longo \& Zouhar, 2019; Pustovrh, Rangus \& Drnovšek, 2020). Incubation programmes rely on the support of business incubators (Baraldi \& Havenvid, 2016; Diez-Vial \& Montoro-Sanchez, 2017; Xiao \& North, 2018). Thus, business incubation is a set of programmes that assist entrepreneurs in growing their businesses more quickly by offering a range of business support services and resources that are formed or coordinated by business incubation management and made accessible both within the incubator through its network of contacts (NBIA, 2007), the use of business support services, infrastructure, and networking.

Incubators have been identified as one of the most important players in the support and eventual development of small businesses (Lose \& Kapondoro, 2020; Kiran \& Bose, 2020). As a result, a great number of business incubators have sprung up to help SMEs become more sustainable and lucrative. According to AlKasasbeh, Alhalameh, and Lehyeh (2017) business incubation helps ailing businesses by providing a variety of services such as business networking, affordable office space, training facility/coaching, legal counselling/ intellectual 
property, office equipment, business plan and product development, as well as computer equipment/services.

According to Zapata et al. (2021) and Lukes et al. (2019), incubators are seen as a great support for entrepreneurs from an operational or business standpoint, as they provide an adequate ecosystem for the formation of new businesses, assisting them in recognizing new business opportunities as well as providing assistance in the three basic functions of entrepreneurship: innovation and technological development, financial risk, and administrative management.

Furthermore, business incubators are not only important organisations for the growth and development of new enterprises, they are also important for their formation (Lukeš et al., 2019). Similarly, it has recently been demonstrated that incubators aid in the development of start-ups and innovation (Lukeš et al., 2019; Zapata et al., 2021).

Few studies have focused on the role of incubators in supporting project holders in emerging countries and, particularly, in Algeria. We were influenced by some of the previous studies, such as a study by Arabeche \& El Amin (2021). The authors found that the young age and the lack of practice in the field of the project holder presented difficulty in the creation of a company. Chekroune and Abedou (2020) in their study found that innovative project leaders (ICT) were mainly young men with a high level of education and who were, in the majority of cases, from engineering schools or universities. Their creation projects were not related to the content of their university. The research by Ali (2017) also highlighted that the creation of technological parks in Algeria was part of the process granting a priority to the promotion of the digital economy and innovation in the ICT sector through the creation of start-ups.

To begin with, evaluation studies are carried out in the most developed nations (Hsu et al., 2003). Yet, few studies, particularly statistical studies, have been conducted in poor countries on incubator experience in aiding young project holders (Akcomak \& Taymaz, 2007)

Second, most research is dependent on incubating evaluations rather than the incubator (Lofsten \& Linfelof, 2007).

Thirdly, support increases the chances of survival of incubated projects in addition to creating new projects and job opportunities. Statistics show that survival rates are generally much lower for non-incubator companies. But there is some evidence from studies that do not support these general statistics. In Germany, for example, only $3 \%$ of entrepreneurs started their projects under the guidance of an incubator (Tamasy, 2007).

The objective of this article is to show the state of affairs of the incubator of Sidi Abdellah. The paper demonstrates the actions carried out during the period of 2010-2020 to encourage entrepreneurship, innovation and technology. The research problem is articulated around the following question: What are the main achievements led by the incubator of Cyber-park since its appearance until today to accompany the young people? To answer the question, we have formulated the following hypothesis in order to verify it in the second part: The Cyber park has generated satisfactory results in terms of projects completed at the end of the incubation phase. 


\section{INCUBATION BUSINESS AND ENTREPRENEURSHIP: LITERATURE REVIEW}

Small and medium-sized enterprises (SMEs) are vital for developing country competitiveness and the development of major innovation systems. It is critical to improve the business climate and strengthen SME capacity to take advantage of trade and investment possibilities in order to promote SME growth (Safari, 2020). Therefore, these companies and especially the start-ups need support and followup, in other words, an incubator.

The concept "incubator" was proposed in the United States by researchers in the hard sciences. The Larousse Encyclopedia (2005) indicates that an incubator is "a device used for the artificial incubation of eggs of hens, geese, etc." Thus, it is a "protective action of the parents, or of one of the parents, when they cover their eggs with their body (brooding birds) or shelter them in a body cavity" (Mohamed, 2007). As a result, this instrument has evolved from a method of assisting live creatures in their evolution to a support framework for young entrepreneurs in their business formation processes and during the early stages of their operations (Arabeche \& El Amin, 2021).

In basic terms, a business incubator, according to Setiawan (2003), is a small facility with a group of well-trained management personnel that provides a shared place/space for company, business facilities, and access to technical services and business in one cheap package. This assistance is required for new businesses since it can decrease the burden of early expenditures through the use of cost-sharing system among the tenants. Furthermore, if the business incubator is seen as a system-process, the following indications may be discovered in the business incubator: (1) as a consequence of the selection process, the potential entrepreneurs are referred to as renters; (2) the incubator's and tenant's needed facilities; (3) management personnel who function as a facilitator, trainer, or consultant for tenants; (4) management, technological, or entrepreneurship curriculum tailored to the needs of tenants; (5) teaching or mentoring methods; (6) the local environment in which the business incubator operates, such as farming communities, craftsmen communities, traders, and so on; (7) output, i.e. tenants who have completed a business incubator programme and are now self-employed. As shown in Fig. 1, this explanation might be given in a variety of ways (Setiawan \& Fahmi, 2019).

First of all, we need to know the conditions and context of the incubator in order to understand its main roles. Creating an organisation is a very complex process, regardless of the type of project, the level of training of the entrepreneur, or the support available to them. From the intention to create a company through the implementation of all the phases necessary for the creation of this company, it is possible that the entrepreneurs who start their activity can find themselves facing enormous difficulties and problems. For these reasons, there are support mechanisms for entrepreneurship. 


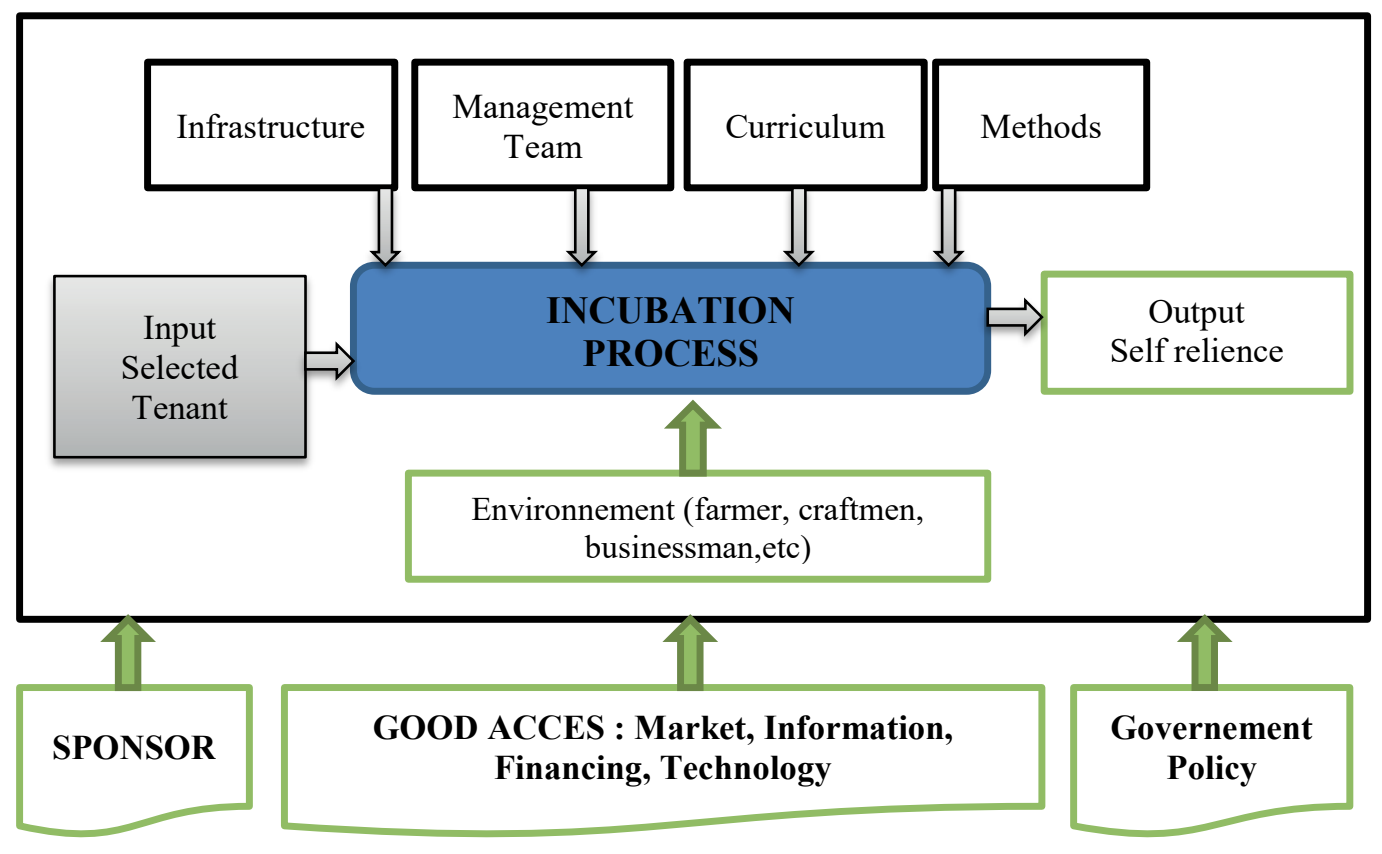

Fig. 1. The process of business incubation (Setiawan \& Fahmi, 2019).

According to Masmoudi (2007, p. 53), the subject of entrepreneurship support is generally used by researchers to refer to "various mechanisms for assisting entrepreneurs and enterprises in start-up and/or difficulty". For Brazauskaite and Auruskeviciené (2017) SMEs and start-ups need to be innovative in order to ensure their performance. This requires a favourable economic system.

Bruyat (1993) identifies three main objectives for support structures. The first objective is to raise people's awareness through communication and information. The second objective is to limit the number of failures by supporting, accompanying, and training project leaders. Finally, the third objective is to ensure that entrepreneurs have greater development opportunities through accommodation and financing systems (Bruyat, 1993).

Support in entrepreneurship also refers to other commonly used terminologies, such as coaching and support. Many authors (Bruyat, 1993; Masmoudi, 2007; Cuzin \& Fayolle, 2005); admit that the subject of entrepreneurship support has received less attention than other facets of entrepreneurship. Masmoudi (2007) identifies two strands of support for entrepreneurship. The first, retained by Bruyat (1993), is a broad component of support, including all support instruments "with awareness-raising, reception and orientation of new entrepreneurs or project holders, information and networking, accompaniment, advice and follow-up, training (short or long), logistical support (secretariat, management, etc.), financing, establishment, etc." The second component, described as narrow, focuses mainly on a specific aspect of support, such as financial support, advice, coaching, and logistics. 


\section{EMPIRICAL REVIEW}

\subsection{Presentation of the Technological Poles in Algeria}

The Algerian authorities have put in place a strategy to establish four technology poles installed on the national territory and it is part of the development plan PNAT 2025 and the economic development plan since 2002. This reflects the Algerian desire to draw inspiration from the experiences of neighbouring countries. Fig. 2 shows the location of the technological poles in the four parts of the country. Starting with the pole of Sidi Abdellah, which is located in the center of Algeria, it is focused on ICT, university research and training and advanced technologies. Thus, there is the Technopark of the wilaya of Oran, which connects the wilaya of Sidi Belabass and Mostaganem for the specialization of organic chemistry, telecommunications and space technologies (western part). In addition, in the east side, the pole of Annaba is set up by connecting the wilayas of Sétif, Bordj Bou Arreridj and Bejaia for the development of the food biotechnology, the plastics industry and production technology. Finally, the Technopark in the south, which connects Hassi Messaoud and Ghardia, specializes in the field of petrochemistry and Saharan agriculture and ICT (Boumedini \& Signoles, 2017).



Fig. 2. The main technological poles in Algeria, National Spatial Planning Plan for 2030, Algiers, 2001 (Boumedini \& Signoles, 2017).

The incubator of Sidi Abdellah Cyber-park focuses on the digital sector, it sees itself as a catalyst of new information technologies and communication, the engine of creation and innovation for an objective to move Algeria from a traditional economic mode to a digital mode.

In fact, several applications have been created and developed within the Sidi Abdellah incubator, for example, the "E-Tabib" application in order to fight against the coronavirus epidemic by offering a free virtual medical consultation space (Hamza \& SM, 2020). There is also the "MadrassaNet" application, which presents a platform dedicated to online learning for different levels. This approach promotes 
entrepreneurship and innovation through qualified human capital in the ICT field (Center, 2020).

There is a will on the part of the Algerian authorities to establish real technological poles to diversify the economy and turn to ICTs, however, progress in this strategy remains timid, long and unsatisfactory compared to the objectives set.

\subsection{Method and Data Sources}

The field study included the National Agency for the Promotion and Development of Technology Parks in Algiers, Algeria. We have relied on the case study methodology, which is recommended for use in management science, as it allows the researcher to approach the phenomenon under study in order to understand and deepen it. Documents are an important method of gathering information as they reflect the reality of the Agency in supporting young project holders. Documents were obtained from certain ANPT departments, which provided us with a great deal of information, including information on the number of young project holders who were sponsored and accompanied during the stages of their business creation, the most important scientific events in which the agency participated, in addition to the most important objectives achieved during the period of 2017-2020.

\subsection{Presentation of the Cyber-park Incubator in Algiers}

The incubator has an important role in the accompaniment and the support of the creators of companies. We can notice that they are few in the Algerian context. The Algerian State wishes to diversify its economy and needs much more supervision and support for the different companies by pushing them to develop. We conducted our study in one of the incubators of Algiers, the incubator of Sidi Abdellah (see Fig. 3).

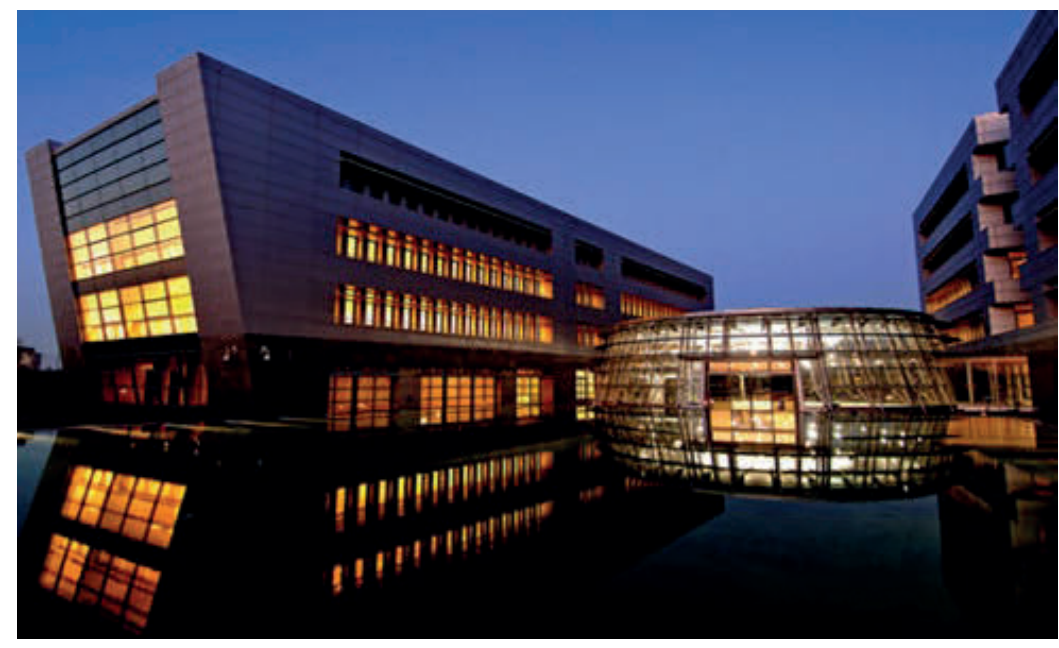

Fig. 3. Technological park of Sidi Abdallah, Algiers (NATP, 2020). 
Park presents the first experience of the creation of a technological park launched in Algeria in 2010. This creation reflects a strong political and economic will to accelerate Algeria's transition to an economy focused on innovation and knowledge. We conducted an interview with the head of the Directorate of Incubation and Training (DIF) on the status of the incubator of Sidi Abdellah and the main actions, objectives and achievements of the incubator during the last years. We retained some answers and documentation that we found interesting (NATP, 2020).

\section{RESULTS AND FINDINGS}

According to the survey conducted under the direction of ANPT, we were able to summarise the main actions, objectives, and results during the years 2010, 2016, 2017, 2018, 2019, 2020.

\subsection{Actions Initiated from 2010 to 2020}

We note from the balance sheet of the year 2010, that the incubator of Sidi Abdellah implemented several plans to achieve them for the support of young project holders. The incubator was able to achieve several different actions according to the table below: support and incubation, training of entrepreneurs, conventions, seminars, the concretization of the technological park in ICT, etc.

Table 1. Objectives, Actions and Results of the Year 2010

\begin{tabular}{|c|c|}
\hline Actions & $\begin{array}{l}\text { - Incubation and support programmes for young project holders and start-ups, } \\
\text { consisting of accompaniment and incubation process spread over several phases. } \\
\text { - Development of training programmes in the fields of ICT and digital } \\
\text { entrepreneurship for young project holders and start-ups. } \\
\text { - Development of the network of incubators and technological parks, spread } \\
\text { throughout the national territory. } \\
\text { - Promotional events on the contribution of entrepreneurship in innovation. } \\
\text { - Realisation of technological experience centres in partnership with major } \\
\text { publishers or on own funds such as a test platform Pre-5G, and a recording studio. } \\
\text { - Launching of calls for tender for the realisation of ICT projects, financed by the } \\
\text { FAUDTICRSFR, with a lighter procedure for start-ups. }\end{array}$ \\
\hline Objectives & $\begin{array}{l}\text { - To offer adequate training in the technical fields for the creation and management } \\
\text { of the company. } \\
\text { - To facilitate the creation of companies and to reinforce the reception capacities } \\
\text { of students and young ICT project holders and start-ups. } \\
\text { - To develop the network of partners of the young project holders and start-ups } \\
\text { supported. } \\
\text { - To treat the major subjects of the current events in the field of entrepreneurship, } \\
\text { and ICT. } \\
\text { - Technological appropriation for the benefit of students, start-ups, and project } \\
\text { leaders. } \\
\text { - Technical capacity building of students and project leaders and ICT start-ups. }\end{array}$ \\
\hline
\end{tabular}





Source: documents provided by the National Agency for the Promotion and Development of Technological Parks, 2020.

All this is part of the efforts made by the national agency for the promotion and development of technological parks whose mission is to "develop an ecosystem conducive to ICT through the creation of technological parks" and to establish an entrepreneurial culture and innovation.

Table 2. Objectives, Actions and Results of the Year 2016

\begin{tabular}{|c|c|}
\hline Actions & $\begin{array}{l}\text { Development of international cooperation programmes, e.g. Algeria/Tunisia, } \\
\text { Algeria/EU, Algeria/Germany, consisting of: } \\
\text { Signature of several cooperation agreements with foreign companies and } \\
\text { technological institutions. } \\
\text { - Soft landing programme. } \\
\text { - Organisation of several events and workshops. }\end{array}$ \\
\hline Objectives & $\begin{array}{l}\text { - } \quad \text { Technology and skills transfer. } \\
\text { - } \quad \text { Strengthening the technical capacities of project leaders and ICT start-ups. } \\
\text { - } \quad \text { Establishment of international synergy between Algerian start-ups and their } \\
\text { foreign counterparts. } \\
\text { - } \quad \text { Strengthening the mobility of start-ups with partners. }\end{array}$ \\
\hline Results & $\begin{array}{l}\text { - Organisation of more than } 10 \text { trips of Algerian start-ups abroad (Germany, } \\
\text { Tunisia, France, Spain, Asia, etc.). } \\
\text { - Signature of a cooperation agreement with the German Federal Ministry of } \\
\text { Economic Affairs and Energy and with foreign companies and technological } \\
\text { institutions. } \\
\text { - Organisation of more than } 25 \text { study days, workshops and events. }\end{array}$ \\
\hline
\end{tabular}

Source: documents provided by the National Agency for the Promotion and Development of Technological Parks, 2020. 
The incubator of Sidi Abdellah has succeeded in granting several international conventions with Tunisia, the European Union in order to promote the start-up sector in innovation and ICT. According to the director of ANPT (Abdelhakim, 2020), the Cyber-park incubator operates with its own budget and reinvests in the supervision and coaching of young project holders.

For the year 2017, the incubator has always relied on the rooting of the entrepreneurial culture and the support of young people through training days and awareness.

Table 3. Objectives, Actions and Results of the Year 2017

\begin{tabular}{|l|l|}
\hline Actions & $\begin{array}{l}\text { ICT training programme (100 days spread over } 6 \text { months) of high level for the } \\
\text { benefit of students, project leaders and ICT start-ups at the level of the ICT } \\
\text { experience centre of ANPT. }\end{array}$ \\
\hline Objectives & $\begin{array}{l}\text { Technological appropriation for the benefit of students, start-ups and project } \\
\text { leaders. }\end{array}$ \\
\hline Results & $\begin{array}{l}\text { Realisation of } 100 \text { days of training with the participation of more than } 100 \\
\text { learners. }\end{array}$ \\
\hline
\end{tabular}

Source: documents provided by the National Agency for the Promotion and Development of Technological Parks, 2020.

Table 4. Objectives, Actions and Results of the Year 2018

\begin{tabular}{|c|c|}
\hline Actions & $\begin{array}{l}\text { Programme "e-Commerce \& e-Payment" consists of: } \\
-\quad \text { Partnership agreement with Algeria Post and GIE Monétique. } \\
-\quad \text { Organisation of events dedicated to the subject. } \\
-\quad \text { Training of start-ups in the integration of online payment. }\end{array}$ \\
\hline Objectives & $\begin{array}{l}\text { - Promotion of online payment and e-Commerce. } \\
\text { - Inclusion of start-ups and project leaders to support national needs in terms } \\
\text { of adapted solutions. }\end{array}$ \\
\hline Results & $\begin{array}{l}\text { - } \quad \text { Signing of } 2 \text { partnership agreements with Algérie Poste and GIE Monétique. } \\
-\quad \text { Organisation of } 5 \text { study days around e-Payment and e-Commerce. } \\
-\quad \text { Training of } 10 \text { start-ups in the integration of e-payment. } \\
-\quad \text { Realisation of } 4 \text { projects. }\end{array}$ \\
\hline \multicolumn{2}{|c|}{$\begin{array}{c}\text { Development of training programmes in line with the needs of young project holders and } \\
\text { innovative start-ups, as well as those of the ICT and digital entrepreneurial ecosystem and } \\
\text { the labour market }\end{array}$} \\
\hline Actions & $\begin{array}{l}\text { Full Stack Web Developer programme consisting of: } \\
\text { - } \quad \text { A complete training course in Web development (40 days spread over } 6 \\
\text { months). } \\
\text { - } \quad \text { Dedicated recruitment days "Digital Job Day". } \\
\text { - Recruitment/training programme for upgrading and pooling developers. } \\
\text { IoT/Arduino/LoraWan programme consisting of: } \\
\text { - } \quad \text { Arduino training programme. } \\
-\quad \text { Organisation of events dedicated to the subject. } \\
-\quad \begin{array}{l}\text { Development of inter-institutional, national and international partnerships } \\
\text { related to the IoT field. }\end{array}\end{array}$ \\
\hline
\end{tabular}




\begin{tabular}{|c|c|}
\hline Objectives & 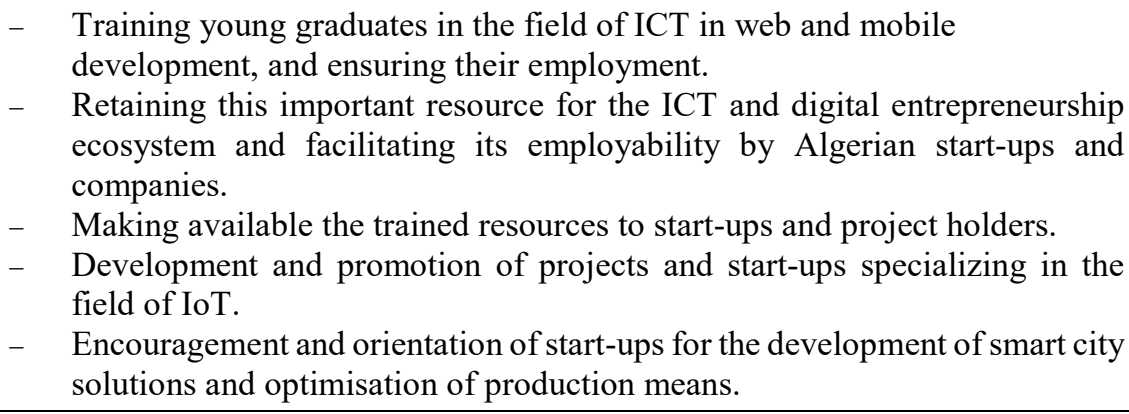 \\
\hline Results & 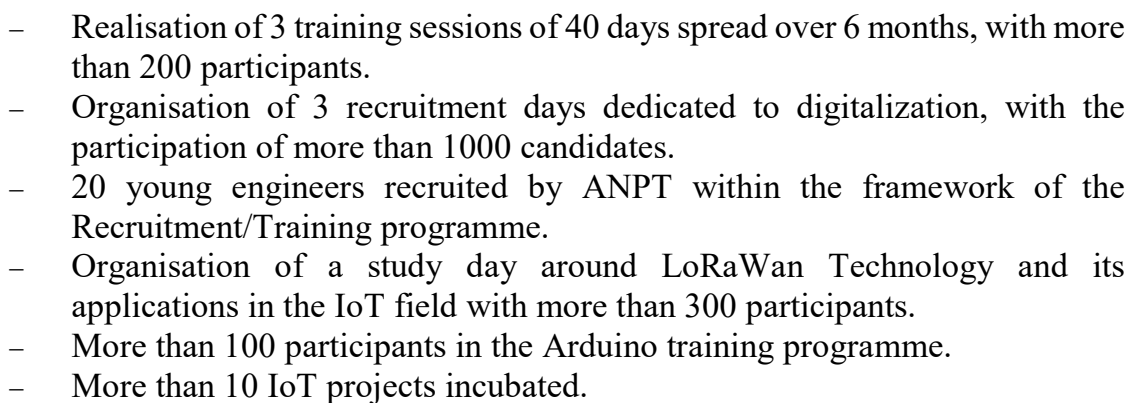 \\
\hline
\end{tabular}

Source: documents provided by the National Agency for the Promotion and Development of Technological Parks, 2020.

It can be noted that the incubator of Cyberpark began to work rigorously on the issues of new information technologies and communication during the year 2018 via the partnership with Algeria Post and GIE Monétique and moved to the training of e-commerce and e-payment where the concrete realization of 4 start-ups in ICT was achieved. The incubator continued to give training, open days, and seminars dedicated to youth in entrepreneurship and ICT.

Table 5. Objectives, Actions and Results of the Period 2019-2020

\begin{tabular}{|c|c|}
\hline Actions & $\begin{array}{l}\text { - } \quad \text { SAP Young Professional Programme } \\
\text { Digital Transformation programme consists of: } \\
\text { - } \quad \text { Training courses dedicated to the subject. } \\
-\quad \text { Organisation of events and workshops. } \\
-\quad \text { Accompaniment and support. }\end{array}$ \\
\hline Objectives & 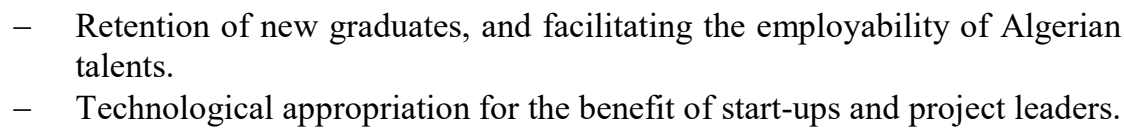 \\
\hline Results & $\begin{array}{l}\text { - } 2 \text { training sessions organised. } \\
\text { - } 60 \text { consultants trained, certified and placed in Algerian companies. } \\
\text { - } \quad \text { More than } 30 \text { days of training organised with the participation of more } \\
\text { than } 100 \text { learners }\end{array}$ \\
\hline
\end{tabular}

Source: documents provided by the National Agency for the Promotion and Development of Technological Parks, 2020. 
For the period of 2019-2020, we can point out that the Cyber-park provides more training and coaching sessions to project holders with professional executives. The incubator always has this capital role of support of accompaniment of the companies. It can be stated that the incubator of Sidi Abdellah presents a good public experience in establishing a valid ecosystem that aims at developing the startups in all the sectors and particularly in ICT to promote the economic growth of the country.

\subsection{Summary of the Work Done by the Cyber-Parc Incubator in 2020}

The National Agency for the Promotion and Development of Technological Parks organises and manages these structures. which are located in Bel Abbes (SBA), Oran, the University of Bord Bou Arreridj (BBA), Annaba, Bel Abbes and Ouargla. Thus, it provides them with various technological means necessary for the establishment of poles of excellence in new information technology and communication.

According to Fig. 4, we can notice that the young project holders register in an important way during Phase 1 and Phase 2. The carriers of projects in these phases present their projects in front of the persons in charge of the incubator to take their validation.

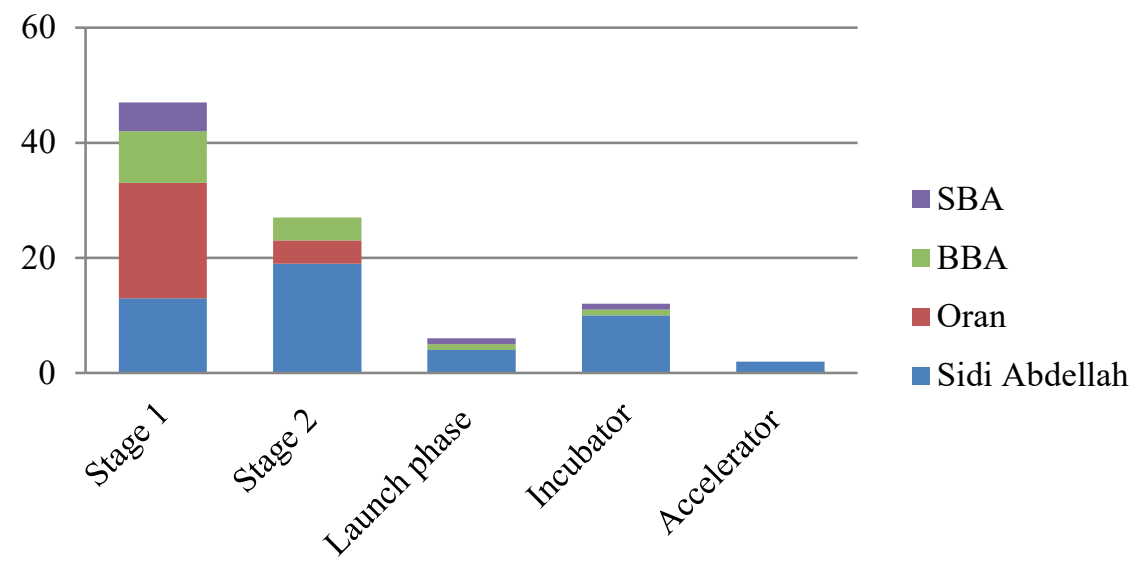

Fig. 4. Number of project leaders and start-ups per site and per support phase (image at the end of March 2020). (The author's contributions based on the documentation provided by NATP, 2020).

In fact, several meetings can be fundamental for the persons in charge in order to have a precise knowledge on the completeness of the project. After an analysis and study with the members of the incubator, the direction decides whether to continue the project set up. This way, a few "valid" projects pass to the launching phase. Also, it can be noted that there are few project holders who have launched their businesses, much more in the Cyber-park of Sidi Abdellah. This is explained by the seniority of this structure compared to other annexes installed in Oran, Bord Bou Arreridj (BBA), and Bel Abbes as part of training and awareness. 


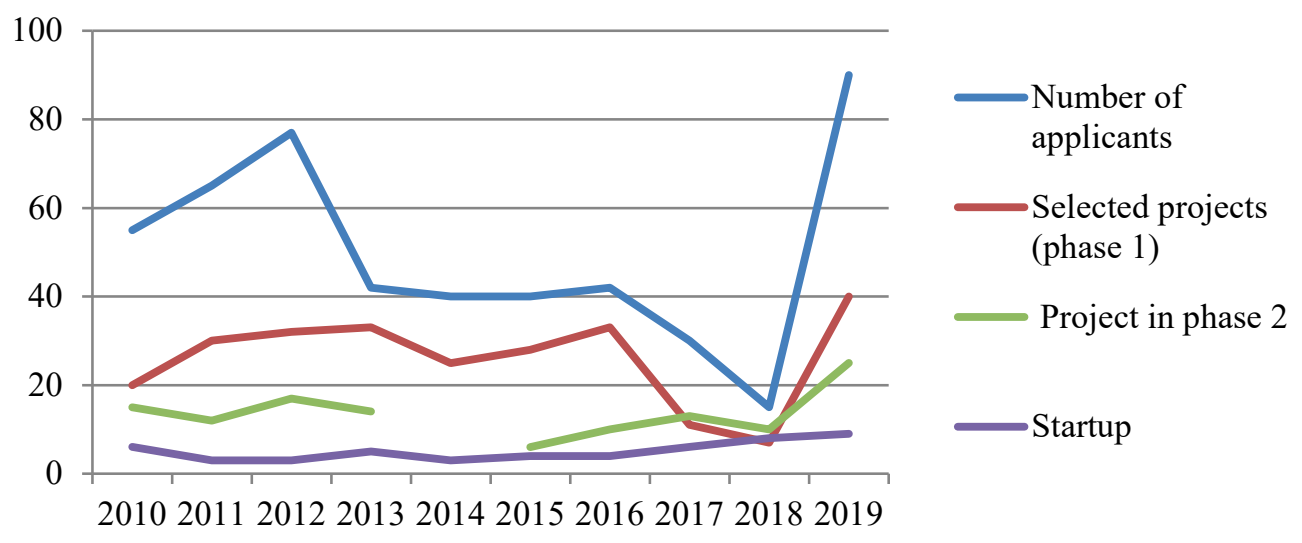

Fig. 5. History of the activity (the author's contributions based on the documentation provided by NATP, 2020).

Fig. 5 shows that the number of registered applicant projects evolved from the year 2010 to the year 2013 and then experienced continuous disruption until the year 2018. The selected projects show growth from 2016 to 2019; however, we note that start-up realization remains low compared to the registered projects. This weakness can be justified by the incubator's lack of expertise, lack of funding, and lack of qualified human resources to make these start-ups a success.



Fig. 6. Training courses held during the $1^{\text {st }}$ quarter of 2020 (the author's contributions based on the documentation provided by NATP, 2020).

The Sidi Abdellah incubator offers several different trainings and courses. Fig. 6 shows that the training "Web Development" is a priority for a significant number of participants, 109 people between project leaders and employees of the ANPT. Then, the courses "Digital Transformation" and "Entrepreneurship and Business Creation" come in the second place in terms of training courses followed in the first quarter of 2020. Finally, "Security of Information Systems" and "Office 
Automation (Word \& Excel)" present the least important courses in terms of the number of participants, number of sessions and duration (days).

Table 6. History of the Activity

\begin{tabular}{|l|l|l|l|l|l|l|l|l|l|l|l|}
\hline & $\mathbf{2 0 1 0}$ & $\mathbf{2 0 1 1}$ & $\mathbf{2 0 1 2}$ & $\mathbf{2 0 1 3}$ & $\mathbf{2 0 1 4}$ & $\mathbf{2 0 1 5}$ & $\mathbf{2 0 1 6}$ & $\mathbf{2 0 1 7}$ & $\mathbf{2 0 1 8}$ & $\mathbf{2 0 1 9}$ & Total \\
\hline No. of events & 13 & 14 & 15 & 12 & 16 & 19 & 20 & 13 & 20 & 24 & 166 \\
\hline $\begin{array}{l}\text { No. of } \\
\text { participants }\end{array}$ & $/$ & $/$ & $/$ & $/$ & $/$ & 1200 & 1800 & 850 & 2500 & 3300 & 9650 \\
\hline
\end{tabular}

Source: documents provided by the National Agency for the Promotion and Development of Technological Parks, 2020.

According to Table 6, the number of events elaborated by the incubator of Sidi Abdellah has evolved since 2013 from 13 events until 24 events recorded in 2019. At the same time, 3300 participants were committed to participate in this kind of event in 2019 after 1200 in 2015. This demonstrates awareness of business creation and support mechanisms.

During the year 2020, the incubator of Sidi Abdellah set up several and different events in order to develop a favourable ecosystem for start-ups and SMEs through the encouragement of the entrepreneurial spirit among young people and project holders.

Table 7. Consolidated Table of Events Organised during the $1^{\text {st }}$ Quarter of 2020

\begin{tabular}{|l|c|c|}
\hline \multicolumn{1}{|c|}{ Event } & Date & $\begin{array}{c}\text { Number of } \\
\text { participants }\end{array}$ \\
\hline $\begin{array}{l}\text { Event visit of the Wali of Algiers to the Technopark Sidi } \\
\text { Abdellah }\end{array}$ & $11 / 01 / 2020$ & 100 \\
\hline Global Internet Exchange event in Algeria & $27 / 01 / 2020$ & 150 \\
\hline Open day Incubator Sidi Abdellah & $30 / 01 / 2020$ & 150 \\
\hline 5G Algeria 2020 event & $05 / 02 / 2020$ & 300 \\
\hline Visit of German experts with workshops and meetings & $17 \& 18 / 02 / 2020$ & 45 \\
\hline $\begin{array}{l}\text { Visit of the ICT centre of excellence and signing of the } \\
\text { convention }\end{array}$ & $18 / 02 / 2020$ & 100 \\
\hline Meetup between new and old start-ups & $19 / 02 / 2020$ & 50 \\
\hline Visit of German experts with workshops and meetings & $23 \& 24 / 02 / 2020$ & 25 \\
\hline Launch of the Sidi Belabes incubator and open day & $27 / 02 / 2020$ & 85 \\
\hline Incubator open day Oran & $05 / 03 / 2020$ & 60 \\
\hline $\begin{array}{l}\text { Inauguration of the recording studio with an online live } \\
\text { on female entrepreneurship }\end{array}$ & $08 / 03 / 2020$ & 75 \\
\hline Total: & 13 days & 1140 \\
\hline $\begin{array}{l}\text { Source: documents provided by the National Agency for the Promotion and Development of } \\
\text { Technological Parks, }\end{array}$ & \\
\hline
\end{tabular}

Technological Parks, 2020. 
According to Table 7, we can see events such as the visit of Algerian and foreign officials at the headquarters of Technopark; incubator open days and the inauguration of the recording studio dedicated to women entrepreneurs.

\section{CONCLUSION AND DISCUSSION}

Incubators play a key role in increasing the performance of start-ups and SMEs by developing their competitiveness. Incubators enable start-ups and SMEs to meet several challenges by providing the necessary climate to support projects, by continuously monitoring the ideas of incubator-affiliated project holders, and by discovering creative abilities and turning them into productive projects. From what we have noticed through our work, Algeria has issued several decrees to set up incubators, including the Sidi Abdallah incubator, which is the first incubator in Algeria and works to accompany start-ups from the appearance of the idea until its realization. Therefore, since its inception, it has tried to give a distinct image as a leading project within the technological incubators by educating young people in general and project holders in particular, as it has worked since its foundation to offer many meetings, seminars, open days, in order to raise awareness and root an entrepreneurial culture and innovation.

It has also linked the university to the external environment through the establishment of business incubators near universities, research centers and scientific cities (The Scientific Village of Sidi Abdullah), concluding many agreements with partners inside and outside the country in the field of innovation and new technologies, all these works worked by the incubator Sidi Abdullah since its establishment today. However, through our reading of the statistics provided, we can say that the number of project holders affiliated to the incubator Sidi Abdullah, especially the number of projects accepted, is still far from the objectives presented by the incubator, and should therefore not only strengthen the side of events and study days. This finding is related to the work of Taouaf et al. (2019), who state that in the Moroccan context the number of projects supported by the various Moroccan support mechanisms remains very low and the number of enterprises created is even lower.

This allows us to say that our hypothesis has not been confirmed; the incubator must have a strong will to strengthen its place in the whole national territory by listing the most important services it provides to project holders and being able to find funding for projects because we want it or not, new projects need mainly funding, so the incubator must implement a radical solution to this "classic" problem, which still preoccupies entrepreneurs to this day.

The results of the study are closely related to the research of Masmoudi (2017), Bizindavy (2014), and Wang et al. (2020) who confirm that incubators present a tool that can help young project holders to become real entrepreneurs and create employment opportunities for graduates, also reducing the unemployment rate. Incubators, therefore, present a factor for idea creation and business development and commercialization. The results of our study are also related to the work of Zhao et al. (2017) and Bruneel et al. (2012) who focus on the role of incubators in three 
main services: basic services (coaching, secretarial support, workspace), financing services and incubation.

However, in terms of financing, our investigation shows that there is a significant lack of financing for innovative projects, which reflects a sad reality for the initiation of value-adding projects. It is due to the fact that the Algerian financial support landscape has long suffered from a lack of formal commitment from its traditional financing institutions in favour of business creation. They focus on very strict granting criteria that are unsuitable for project holders. On the other hand, in the Tunisian context, there are more facilities for entrepreneurs to have access to financing through several financing mechanisms (incubators, SICARs, FOPRODI) (Masmoudi, 2007).

\section{LIMITATIONS OF THE STUDY AND FUTURE STUDIES}

Despite the efforts of the author, this article has some limitations. The first limitation is the sample size. Future studies should use a bigger sample size to achieve a better understanding of the research phenomena or make a comparison between incubators in Algeria and/or outside Algeria.

Secondly, the use of a questionnaire intended for project leaders will be better for having a precise analysis of the role of incubators in supporting entrepreneurs. The third limitation is the research methodology. Future studies should use quantitative methodology to better understand the phenomenon.

Future study will be able to test the link between young project leaders' assistance and economic performance in Algeria, specifically in the case of the Sidi Abdellah incubator.

\section{ACKNOWLEDGEMENT}

Thanks to the staff of the National Agency for the Promotion and Development of Technological Parks, Cyberpark Sidi Abdellah Rahmania Zeralda, Algiers, Algeria for providing the access to different documents.

\section{REFERENCES}

Abdelhakim, B. (2018). Status report on the SidiAbdellah incubator. Retrieved from https://radioalgerie.dz/news/fr.

Akcomak, I. S., \& Taymaz, E. (2007). Assessing the effectiveness of incubators: The case of Turkey (ERC Working Papers 0412). ERC - Economic Research Center, Middle East Technical University. Retrieved from https://ideas.repec.org/p/met/wpaper/0412.

Ali, M. (2017). Formation and stability of territories dedicated to Information and Communication. Revue de performance des entreprises algériennes, 12, 11-32.

Al-Kasasbeh, M., Alhalameh, M., \& Lehyeh, S. (2017). Business incubators and its effect on success of incubated firms in Jordan. International Business Management11 (1), 189-193. Retrieved from https://medwelljournals.com/abstract/?doi=ibm.2017.189.

Arabeche, Z., \& El Amin, M. A. (2021). The new trends technology of entrepreneurship in the incubators: A case study of cyber-parc Sidi Abdallah. In Big data for entrepreneurship and sustainable development (1st ed.). UK: CRC Press, Taylor and Francis Group. 
Baraldi, E., \& Havenvid, M. I. (2016). Identifying new dimensions of business incubation: A multilevel analysis of Karolinska Institute's incubation system. Technovation, 50-51, 53-68. https://doi.org/10.1016/j.technovation.2015.08.003

Bizindavy, A. (2014). Le processus d'incubation d'entreprise et les petites entreprises touristiques des pays en voie de développement: étude de cas sur le Burundi, en Afrique de l'Est. Canada: Mémoire. Montréal (Québec, Canada), Université du Québec à Montréal, Maîtrise en développement du tourisme.

Boumedini, R. S., \& Signoles, P. (2017). New towns in Algeria: apparently no problem anymore, but a complex reality (Les villes nouvelles en Algérie: une question apparemment réglée, mais une réalité complexe), Les Cahiers d'EMAM, 29. https://doi.org/10.4000/emam.1323

Brazauskaité, I., \& Auruskeviciene, V. (2017). Moderating role of environmental settings in relationship between product innovativeness and its performance during the launch. Economics and Business, 31(1), 44-54. https://doi.org/10.1515/eb-2017-0017

Bruneel, J., Ratinho, T., Clarysse, B. \& Groen, A. (2012). The evolution of business incubators: Comparing demand and supply of business incubation services across different incubator generations. Technovation, 32(2), 110-121. https://doi.org/10.1016/j.technovation.2011.11.003

Bruyat, C. (1993). Création d'entreprise: Contributions épistémologiques et modélisation(Thèse de doctorat en sciences de gestion., Université Pierre Mendès), Ecole Supérieure des Affaires.

Center, M. (2020). Madrassanet. Consulté le 2020, sur Madrassanet.

Chekroune, N., \& Abedou, A. (2020). Profils et accompagnement en situation entrepreneuriale. Revue organisation et travail, 8(3), 125-144.

Cuzin, R., \& Fayolle, A. (2005). Les dimensions structurantes de l'accompagnement en création d'entreprise. La Revue des Sciences de Gestion. Direction et Gestion, 210, 77-88. https://doi.org/10.1051/larsg:2004040

Diez-Vial, I., \& Montoro-Sanchez, A. (2017). Research evolution in science parks and incubators: foundations and new trends. Scientometrics, 110(3), 1243-1272. https://doi.org/10.1007/s11192-016-2218-5

Hsu, P., Shyu, H., You, C., \& Lo, T. (2003). Exploring the interaction between incubators and industrial clusters: The case of the ITRI incubator in Taiwan. R\&D Management, 33(1), 79-90. https://doi.org/10.1111/1467-9310.00283

Hamza \& SM. (2020). An Algerian startup, etabib 1st Medical Teleconsultation Platform in Algeria. Consulted on 04/092020. Retrieved from http://etabib.dz/

Kiran, R., \& Bose, S. C. (2020). Stimulating business incubation performance: role of networking, university linkage and facilities. Technology Analysis \& Strategic Management, 32(12), 14071421. https://doi.org/10.1080/09537325.2020.1772967

Lofsten, H., \& Linfelof, P. (2007). Science parks and growth of new technology based firms: Academic industry links, innovation and markets. Research Policy, 31(6), 859-876. https://doi.org/10.1016/S0048-7333(01)00153-6

Lose, T., \& Kapondoro, L. (2020). Functional elements for an entrepreneurial university in the South African context; Journal of Critical Reviews, 7(19), 8083-8088. Retrieved from https://www.researchgate.net/publication/344369864_Functional_elements_for_an_entreprene urial_university_in_the_South_African_context

Lukeš, $\bar{M}$., Longo, M. $\bar{C}$., \& ${ }^{-}$Zouhar, J. (2019). Do business incubators really enhance entrepreneurial growth? Evidence from a large sample of innovative Italian start-ups. Technovation, 82-83, 25-34. https://doi.org/10.1016/j.technovation.2018.07.008

Masmoudi. (2007). Exploratory study of processes and incubation models in entrepreneurship: the case of Tunisian nurseries [Doctoral dissertation]. Lyon, France.

Mohamed, R. (2007). Etude exploratoire des processus et modèles [These de doctorat en sciences de gestion].

NBIA, N. B. (2007). Suggested Metrics. NBIA: A Toolkit.

NATP (2020). The National Agency for the Promotion and Development of Technology Parks. Retrieved from https://natp.dz

Pustovrh, A., Rangus, K., \& Drnovšek, M. (2020). The role of open innovation in developing an entrepreneurial support ecosystem. Technological Forecasting and Social Change, 152, Article 119892. https://doi.org/10.1016/j.techfore.2019.119892 
Safari, K. (2020). Contribution of internationalisation to SME growth: Evidence from the Kenyan manufacturing sector. Economics and Business, 34(1), 261-272. https://doi.org/10.2478/eb2020-0017

Setiawan, W. L. (2003). Business incubator in entrepreneurial economic development strategy. Pusat inkubator bisnis ITB, Bandung.

Setiawan, W. L., \& Fahmi, I. (2019). Business Incubator Supporting Diffusion of Innovation. 23rd Asian Forum of Business Education (AFBE 2019), Malang, Indonesia. https://doi.org/10.2991/aebmr.k.200606.041

Tamasy, C. (2007). Rethinking technology-oriented business incubators: Developing a robust policy instrument for entrepreneurship, innovation, and regional development? Growth and change, 38(3), 460-473. https://doi.org/10.1111/j.1468-2257.2007.00379.x

Taouaf, I., Attou, O., El Ganich, M., \& Oulhadj, B. (2019). Concept d'incubation d'entreprises au Maroc: Cas des. Revue de l'entrepreneuriat et de l'innovation, 2(7). Retrieved from https://revues.imist.ma/index.php/REINNOVA/article/view/18015

Wang, Z., He, G., Xia, S., Sarpong, D., Xiong, A., \& Maa, G. (2020). Capacities of business incubators and regional innovation. Technological Forecasting \& Social Change, 158(7), Article 120125. https://doi.org/10.1016/j.techfore.2020.120125

Wonglimpiyarat, J. (2016). The innovation incubator, university business incubator and technology transfer strategy: The case of Thailand. Technology in Society, 46(C), 18-26. https://doi.org/10.1016/j.techsoc.2016.04.002

Xiao, L., \& North, D. (2018). The role of technological business incubators in supporting business innovation in China: A case of regional adaptability? Entrepreneurship \& Regional Development, 30(1-2), 29-57. https://doi.org/10.1080/08985626.2017.1364789

Zapata, G. F. T., Ayup, J., Mayer-Granados, E. L., \& Charles-Coll, J. (2021). Incubator efficiency vs survival of start-ups. RAUSP Management Journal, 55, 511-530. https://doi.org/10.1108/RAUSP-04-2019-0063

Zhao, L., Zhang, H., \& Wu, W. (2017). Knowledge service decision making in business incubators based on the supernetwork model. Physica A: Statistical Mechanics and its Applications, 479, 249-264. https://doi.org/10.1016/j.physa.2017.03.013

\section{AUTHOR'S SHORT BIOGRAPHY}

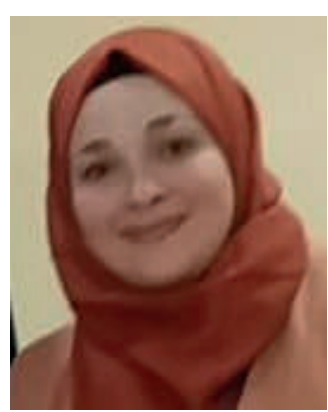

Zina Arabeche received the Master's degree in Management from Tunis El Manar University, Tunisia, in 2010 and the $\mathrm{PhD}$ degree in 2016 from Tlemcen University in Algeria. The author has been an Associate Professor at Ahmed Zabana University of Relizane since 2011.

The main research focuses on entrepreneurship, big data, CSR, sustainable development, performance and organisational culture.

E-mail: zina.arabeche@univ-relizane.dz

ORCID iD: https://orcid.org/0000-0003-3893-3378 